\title{
TEMUAN SEJARAH ATIVITAS PERDAGANGAN KUNO DI DESA DURIAN GADIS SEBAGAI SUMBER PEMBELAJARAN SEJARAH.
}

\author{
Oleh: Muhamad Idris* \\ *Program Studi Pendidikan Sejarah, FKIP Universitas PGRI Palembang
}

\begin{abstract}
ABSTRAK
Desa Durian Gadis menyimpan data sejarah aktivitas perdagangan berupa tembikar dan keramik asing. Permasalahan penelitian: 1) Bagaimanakah temuan sejarah aktivitas perdagangan kuno di desa Durian Gadis?; 2) Bagaimanakah implikasi temuan sejarah aktivitas perdagangan kuno di desa Durian Gadis terhadap pembelajaran sejarah?. Tujuan: untuk mengetahui temuan sejarah aktivitas perdagangan kuno di desa Durian Gadis; 2) Implikasi temuan sejarah aktivitas perdagangan kuno di desa Durian Gadis terhadap pembelajaran sejarah di Program Studi Pendidikan Sejarah FKIP Universitas PGRI Palembang. Metodologi penelitian: deskriptif kualitatif dengan pendekatan arkeologi, keramikologi, ilmu budaya, geologi. Sumber data: informan, dokumen, tempat. Teknik pengumpulan data: wawancara mendalam, kajian dokumen, observasi langsung. Teknik cuplikan di desa Durian Gadis, validitas data dengan teknik triangualasi data dan metode. Teknik analisis yang dipergunakan teknik analisis interaktif. Sejarah desa Durian Gadis memiliki lapisan sejarah zaman Sriwijaya, zaman kesultanan Palembang Darussalam, zaman kolonial, zaman penjajahan Jepang. sejarah desa Durian Gadis bermuatan kelokalan Sumatera Selatan memberikan kontribusi pada pelestarian nilai sejarah dan nilai kearifan lokal, mendorong upaya penelitian dan pembelajaran sejarah lokal Sumatera Selatan. Penelitian dan pembelajaran serpihanserpihan sejarah lokal, menyusun mozaik sejarah Sumatera Selatan yang akan memberikan pemahaman kesejarahan Sumatera Selatan yang utuh melalui pembelajaran sejarah di Program Studi Pendidikan Sejarah
\end{abstract}

Kata Kunci: nilai sejarah, nilai budaya, situs, Durian Gadis.

\section{A. PENDAHULUAN}

Sumatera Selatan memiliki karakteristik sejarah yang unik, berawal dari pemukiman migran nelayan dan petani Austronesia yang datang dari daratan Asia yang membentuk koloni-koloni baru di pantai, lembah dan pegunungan di pulau-pulau kepulauan Nusantara. Koloni ini berkembang selama berabad-abad sebagai dampak kesuburan lahan dengan ketersediaan bahan pangan dan air tawar yang melimpah serta produk perdagangan yang laku di pasar internasional. Kawasan ini tumbuh pesat ditunjang dengan desadesa pantai yang memiliki pelabuhan pantai yang strategis pada jalur-jalur pelayaran tradisional internasional di Selat Malaka, pantai Barat Kalimantan, pantai Utara Jawa, semenanjung Sulawesi, pantai Utara Nusa
Tenggara dan pulau-pulau Maluku (Adelaar, 2004:1-9).

Hasil penelitian arkeologi dan linguistik pada bahasa asli Formosa (Taiwan) menunjukkan bahwa daerah asal bangsa Austronesia mengerucut pada kawasan Taiwan atau kawasan teluk China Selatan. Migrasi bangsa Austronesia ini bermula dari Taiwan ke kepulauan Piliphina ke bagian Barat kepulauan Nusantara. Koloni-koloni migrant Austronesia di kepulauan Nusantara tumbuh dengan membuat pusat-pusat kekuatan politik lokal dengan mengembangkan potensi alam lokal sebagai sumber pertukaran ekonomi internasional (Budisantosa, 2012:47).

Sumatera Selatan merupakan salah satu daerah pemukiman Austronesia di kepulauan Nusantara. Temuan arkeologi penunjukkan bahwa kawasan ini telah 
dimukimi oleh manusia sejak masa prasejarah. bukti-bukti budaya Austronesia masa pra-sejarah ditemukan di kawasan pantai Timur Sumatera Selatan sampai kawasan pegunungan Bukit Barisan (Adelaar, 2004:8).

Temuan arkeologi di Sumatera Selatan menunjukkan bahwa kawasan ini telah melakukan hubungan kebudayaan secara kontinyu dengan dunia luar khususnya dengan kawasan daratan Asia Tenggara. Temuan artefak megalitik, peralatan berburu, tembikar, arca, keramik dan beragam temuan lain menggambarkan nilai strategis kawasan Sumatera Selatan dalam dunia perdagangan di Asia Tenggara (Budisantosa, 2013:69).

Benda-benda perunggu dari Dongson serta keramik Cina dan manik-manik kaca Indo-Pacifik merupakan benda-benda impor yang ditemukan di kawasan ini, sehingga dsimpulkan bahwa kawasan tersebut terlibat dalam jaringan perdagangan maritim Asia Tenggara-Kepulauan Nusantara. Sejak masa pra-Sriwijaya kawasan ini telah terlibat dalam jaringan perdagangan intensif dengan dunia Arab, India dan Cina dengan memperoleh keuntungan sumber daya alam dari dataran tinggi Sumatera. Komoditi bernilai tinggi yang diminati Cina pada abad 12 dari kawasan ini antara lain lilin lebah, madu, cula badak, gading gajah, kayu gaharu, emas, damar (Budisantosa, 2013:69).

Penelitian Sondang $M$. Siregar (Siregar, 2012:12-20) menunjukkan bahwa kebudayaan megalithik Austronesia di Sumatera Selatan yahg mendapat pengaruh Asiatic yang kuat tersebar dari Banding Agung di sekitar daerah sekitar danau Ranau kabupaten Ogan Komering Ulu Selatan. Kebudayaan megalithik yang tersebar di sekitar danau Ranau berupa dolmen, batu datar, batu temu gelang, kubur batu, arca. Temuan lain berupa alat serpih, beragam tembikar, keramik, logam. Keberadaan temuan keramik dari abad 8-12 Masehi menunjukkan bahwa masyarakat di sekitar danau Ranau kala itu telah melakukan kontak dagang dengan dunia luar.

Penelitian Kristantina Indriastuti (Indriastuti, 2012:21-35) menunjukan pola persebaran kebudayaan megalithik di Pasemah mengindikasikan bahwa situs pemukiman di pasemah terdiri dari kelompok bangunan benteng tanah, bangunan hunian, jalan batu, bangunan pemujaan, kubur batu dan bekal kubur yang mengindikasikan adanya hubungan perdagangan masyarakat di dataran tinggi Pasemah dengan daerah asal mereka di daratan Asia Tenggara.

Penelitian Tri Marhaeni S. Budisantosa (Budisantosa, 2013:59-82). Hasil penelitian Budisantosa menunjukkan bahwa komunitas-komunitas masyarakat keturunan Austronesia yang bermukim di Hulu Sungai Rawas disekitar Hilir Napal Licin di sekitar candi Lesung Batu dan Candi Tingkip telah mendapat pengaruh budaya anak benua India dan Asia Daratan sejak abad 8-12 Masehi. Bukti temuan yang menguatkan pendapat ini adalah keramik-keramik Cina sejaman dengan usia situs mengindikasikan telah terjadi hubungan dagang yang kontinyu antara dunia luar dengan komunitas-komunitas masyarakat Austronesia di pedalaman Sumatera Selatan.

Kelompok-kelompok migran Asia secara bertahap selama ribuan tahun datang dan menetap di kawasan Sumatera Selatan membentuk kesatuan-kesatuan pemukiman penduduk dan menyebar daratan di sepanjang sungai-sungai di Sumatera Selatan. Mereka menetap dan menyesuaikan diri dengan lingkungan. Catatan sejarah di Sumatera Selatan menunjukkan adanya kesinambungan sejarah antara masa Paleolitik di Padang Bindu, Kabupaten Ogan Komering Ulu, masa Mesolitik-Neolitik di gua Pandan, masa Paleometalik di Pasemah, akhirnya di dataran rendah dan daerah pesisir dijumpai sisa-sisa kerajaan Sriwijaya dan masa 
Kesultanan Palembang Darussalam (Poesponegoro, 2010:37).

Dunia politik Melayu menempatkan sungai sebagai bagian kekuasaan politik yang penting. Anak sungai, teluk rantau memuat pengertian tentang entitas politik yang tunduk kepada pusat. $\mathrm{Hal}$ ini menunjukkan superioritas pusat sebagai inti kekuatan dan kekuasaan politik yang memiliki peran ekonomi besar dalam perdagangan makro dunia Melayu. Daerah anakan sungai atau sungai skunder di Daerah Aliran Sungai (DAS) merupakan bagian dari perluasan politik. Konteks tersebut menggambarkan aneka pemukiman yang tersebar di sepanjang anak sungai yang diperintah oleh sebuah kekuatan politik di pusat kekuasaan (Coedes, 2014:317).

Dunia politik Melayu menggambarkan hirarki politik pusat dan bawahan dengan memanfaatkan sungai dan anak sungainya sebagai media transportasi publik, transportasi politik dan ekonomi. Pusat sebagai centrum politik, ekonomi dan budaya terletak di sebuah tempat yang strategis untuk mendukung berbagai upayaupaya penggalangan masal (Coedes, 2014:317).

Hubungan perdagangan Hulu dan Hilir di Sumatera Selatan pada abad 8-19, telah menarik perhatian peneliti. Sejumlah buku dan artikel berupaya mengangkatnya menjadi tema tulisan dan penelitian dari berbagai sudut pandang keilmuan, seperti sejarah, arkeologi, lingusitik, sastra, filologi telah menjadi bukti perhatian mereka.

Barbara Watson Andaya (1989) menulis tentang perdagangan pakaian di Jambi dan Palembang pada abad 17 dan 18 Masehi. la menampilkan perkembangan perdagangan pakaian di kedua daerah khususnya Sumatera Selatan. Barbara Watson menampilkan sejarah tekstil Sumatera Selatan dengan menggunakan pendekatan kebudayaan. Kajian Barbara Watson Andaya mampu mengungkap hubungan perdagangan tekstil antara Uluan dan Iliran dan Sumatera Bagian Selatan dengan dunia luar. Tulisan ini mengungkap juga produk-produk perdagangan unggulan yang menjadi daya dorong pembelian tekstil impor dan pasar yang mendorong berkembangnya industri tekstil lokal.

Hubungan perdagangan China dengan Sumatera Selatan dikaji dengan sangat detail oleh Geoff Wade (2009) dengan pedekatan ekonomi dan arkeologi. la menampilkan temuan-temuan data yang menarik di daerah Hulu dan Hilir berkenaan dengan temuan sebaran keramik dan tembikar China. Tulisan ini terasa menarik dengan menampilkan data perkembangan ekonomi pada masa dinasti Sung melalui perdagangan dengan dunia luar khususnya Asia Tenggara.

R.W.Roberts (1986) mengangkat data Palembang sebagai kawasan lliran yang menarik untuk dikuasai dan dijadikan koloni Jawa. Tulisan ini mengurai periodesasi kolonisasi Jawa melalui pendudukan politik sejak masa Majapahit sampai masa Demak dengan menggunakan pendekatan sejarahpolitik. Tulisan ini memberi penjelasan tentang arti penting Palembang dalam politik Jawa, sehingga Palembang layak dikuasai dan dijadikan koloni Jawa.

K.Alexander Adelaar (2004) menulis tentang asal muasal etnis Melayu, daerah asal, migrasi dan klasifikasi etnis Melayu. Pendekatan yang digunakan penulis adalah pendekatan antropologi dan lingusitik serta. Perhatian yang sama walau dengan menggunakan pendekatan yang sedikit berbeda mampu memberi informasi tentang perdagangan antara kepulauan Nusantara dengan Asia daratan.

Penelitian ini saya tertarik untuk membicarakan sejarah Sumatera Selatan dengan memfokuskan pada kajian pelayaran dan perdagangan lliran dan Uluan menggunakan sumber naskah, arsip, cerita rakyat dan data arkeologi di masyarakat Sumatera selatan. Sehingga peneliti menemukan data akurat sebagai upaya untuk mengungkap sejarah 
perdagangan dan pelayaran di lliran dan Uluan pada abad 16 sampai abad $19 \mathrm{M}$.

Pada mulanya saya hanya tertarik untuk meneliti koneksi lliran-Uluan melalui dunia pelayaran, akan tetapi saya menemukan data dengan ditemukannya produk-produk keramik China, Vietnam, Thailand, Eropa dalam jumlah yang besar dibanyak situs dan tempat di Uluan dapat mengindikasikan bahwa terjadi ineraksi perdagangan antara kawasan Uluan dengan dunia luar. Oleh karena itu dalam penelitian ini saya memanfaatkan data-data arkeologi untuk memudahkan pembahasan permasalahan penelitian ini.

Penelitian ini juga memanfaatkan juga data arsip. Arsip yang dipergunakan dalam penelitian ini adalah arsip informasi tentang dunia Indonesia pada masa VOC. Arsip Palembang yang dipergunakan adalah arsip yang tersimpan di lembaga Arsip Nasional Republik Indonesia (ANRI) Jakarta. Melalui pemeriksaan arsip di lembaga tersebut, ditemukan sejumlah arsip yang mencatat tentang Sumatera Selatan pada kurun waktu abad ke 18-19.

Berdasarkan pengamatan atas berbagai karangan tentang Sumatera Selatan seperti Bambang Purwanto, Deddy Irwanto, Johan Hanafiah, Farida, terkesan kebanyakan peneliti sejarah Sumatera Selatan menggunakan sumber-sumber penulis asing seperti dokumen Belanda dan Portugis sebagai bahan kajiannnya. Sedangkan sumber-sumber lisan berupa cerita rakyat, data arkeologi dan sumber lain berupa naskah yang dihasilkan oleh orang Sumatera Selatan sendiri yang bermuatan sejarah belum maksimal dimanfaatkan.

Kondisi ini menurut penulis disebabkan oleh beberapa faktor yaitu pertama: peneliti sejarah beranggapan bahwa sumber berupa naskah merupakan sumber data yang sulit diakses. Pendekatan filologi merupakan disiplin ilmu yang sulit dan rumit sehingga akan mempengaruhi rentang waktu pengerjaan penelitian; kedua: penggunaan data arkeologi terutama temuan artefak memiliki tingkat kesulitan mengakses data dan analisis data temuan yang rumit; ketiga penggunaan data cerita rakyat hanya fiktif sehingga tidak layak untuk dijadikan sebagai sumber penulisan.

Naskah Asal-Usul Raja-raja Palembang koleksi Perpustakaan Nasional $\mathrm{RI}$ yang sudah dipublikasikan pada tahun 2001. Penulis mendapatkan data tentang hubungan Hulu dan Hilir pada masa kesultanan Palembang Darussalam.

Berdasarkan informasi yang penulis dapatkan di lapangan diketahui bahwa di kawasan sungai Komering di kabupaten Banyuasin banyak diketamukan bukti-bukti temuan keramik, keberadaan keramik sebagai produk perdagangan menunjukkan kesinambungan sejarah sejak masa Sriwijaya sampai masa kolonial. Penulis menilai data arkeologi tersebut merupakan data hubungan perdagangan Hulu dan Hilir di Sumatera Selatan yang sezaman dengan temuan keramik, karena keramik memiliki nilai umur yang jelas sesuai dengan masa kekuasaan dinasti di China. Masih banyak data dan informasi yang tersimpan di lapangan yang dapat menjadi sumber primer penulisan sejarah perdagangan di Sumatera Selatan abad 8-19 Masehi, dalam laporan penelitian arkeologi mencatat temuan berupa sebaran keramik asing di kawasan sungai Komering, sungai Ogan dan sungai Musi dari periode pra dinasti Tang, sampai temuan keramik abad 19 pada masa dinasti Qing.

Cerita rakyat yang berkembang di desa Muara Gula, kabupaten Muara Enim, menggambarkan perdagangan garam antara lliran dan Uluan di sungai Lematang. Masih banyak data cerita rakyat lain yang berkembang di kawasan Uluan yang merekam aktifitas perdagangan dan pelayaran di Uluan. Masih banyak cerita rakyat yang belum dimanfaatkan dalam penulisan sejarah Sumatera Selatan. Berdasarkan pengamatan peneliti, publikasi tulisan tentang perdagangan di Uluan belum banyak mengungkap data dan informasi 
dinamika perdagangan di Sumatera Selatan pada masa Sriwijaya sampai masa kolonial. Publikasi Bambang Purwanto tentang ekonomi karet yang sangat menarik justru dimulai pada akhir abad 19.

Sejauh ini usaha untuk menampilkan dinamika perdagangan di Uluan baru terbatas pada pemanfaatan arsip sebagai sumber penulisannya, sedangkan sumber berupa cerita rakyat yang hidup di Sumatera Selatan, data arkeologi, dan sumber naskah belum dimanfaatkan secara maksimal. Berikut ini contoh mengenai pentingnya ketiga kajian di atas. Cerita rakyat yang sampai saat sekarang hidup di masyarakat Sumatera Selatan banyak menampilkan tokoh-tokoh ulama yang berasal dari Hadratul Maut, Yaman dan ulama-ulama yang berasal dari tanah Jawa, Minang dan Palembang yang menyebarkan agama Islam di Uluan. Tokoh-tokoh penyebaran Islam memanfaatkan kegiatan perdagangan sebagai sebagai alat islamisasi di pedalaman. Data arkeologi mencatat sebaran situs makam-makam Islam di sepanjang sungai-sungai penting. Beberapa makam masih dalam keadaan utuh dan asli namun sebagian besar sudah direnovasi masyarakat dengan tidak mengindahkan kaidah-kaidah arekologi. Makam-makam tersebut masih menyimpan cerita rakyat dan struktur bangunannya.

Berdasarkan hal tersebut, jelaslah bahwa bahwa identifikasi yang lengkap, kajian folklore, geografi dan historis yang akurat sangat diperlukan untuk menganalis data cerita rakyat, data arkeologi dan arsip. Dengan demikian, tidak saja dunia perdagangan di Uluan Sumatera Selatan dari kajian arsip dapat diketahui lebih jauh, tetapi yang lebih penting lagi kajian tentang perdagangan dunia Uluan di Sumatera Selatan dari sudut kajian geografi dan arkeologi dapat diungkap untuk melengkapi data dari sudut kajian sejarah. Penelitian ini memanfaatkan data arsip dari arsip Nasional Indonesia dari katalog Palembang yang sudah ditranslitrasi dan dipublikasikan oleh arsip, data arkeologi yang digunakan adalah data arkeologi dari Balai Arkeologi Palembang dan hasil penelitian dosen dan mahasiswa Universitas PGRI Palembang.

Data dan informasi akan perdagangan di Uluran Sumatera Selatan abad 8-20 Masehi dikaji dari beberapa bidang ilmu: geografi, arkeologi dan sejarah yang relevan dengan data, isi dan arsip yang akan dikaji dengan cara yang seksama. Dengan demikian, fungsinya sebagai sebagai alat penjelas data sejarah dapat terlihat. Pada bab pembahasan data arsip, geografi, dikaji dengan metode sejarah, dicocokkan agar terlihat relevansinya. Permasalahan dalam penelitian ini adalah: 1) Bagaimanakah temuan sejarah aktivitas pedagangan kuno di Desa Durian Gadis?; 2) Bagaimanakah implikasi temuan sejarah aktivitas perdagangan kuno di Desa Durian Gadis terhadap pembelajaran sejarah di Program Studi Pendidikan Sejarah FKIP Universitas PGRI Palembang?

\section{B. METODE PENELITIAN}

Berdasarkan rumusan masalah, penelitian ini mendeskripsikan secara rinci dan mendalam tentang dinamika dunia perdagangan di Uluan Sumatera Selatan pada abad 8-20 M. Untuk memahami hal tersebut, dilakukan penelitian secara mendalam dengan menggunakan pendekatan deskriptif kualitatif.

Sumber Data. Sumber data dalam penelitian ini adalah: Informan, Dokumen, Tempat. Teknik Pengumpulan Data: Wawancara Mendalam, Kajian Dokumen, Observasi Langsung

Teknik Cuplikan. Peneliti dalam melakukan kegiatan penelitian ini menggunakan teknik cuplikan purposive sampling.

Validitas Data. Validitas data sangat penting dalam proses pemaparan hasil penelitian, pembahasan dan penarikan simpulan. Dengan adanya validitas data triangulasi yang digunakan: triangulasi data, triangulasi metode. 


\section{HASIL DAN PEMBAHASAN}

Analisis yang dilakukan pada penelitian ini menggunakan analisis model interaktif terdiri atas tiga alur kegiatan yang terjadi secara bersamaan, yaitu reduksi data, penyajian data, dan penarikan kesimpulan.

Data dari barang-barang temuan permukaan dan temuan pada kotak penggalian, menunjukkan temuan terbesar berupa fragmen keramik dan fragmen tembikar dari beragam periodesasi sejarah Sumatera Selatan, yaitu dari masa kerajaan Sriwijaya, Kesultanan Palembang Darussalam, masa kolonial, masa pendudukan Jepang.

Hasil analisis temuan tembikar:

Bentuk: pecahan tembikar yang ditemukan merupakan bagian mulut tembikar dengan diameter $14 \mathrm{~cm}$, tebal 1,2 $\mathrm{cm}$ dan berat $20 \mathrm{gr}$. Bagian mulut ini beroreintasi terbuka dengan fungsi utama memasukan air.

Teknologi: pada bagian dalam tembikar ditemukan striasi yang renggang dan tampak putus-putus (teknik roda putar lambat). Bahan yang dipakai adalah tanah liat dengan partikel kasar dan tekstur renggang. Pembakaran tembikar berada pada tahap reduksi dengan ditemukan warna hitam yang tidak merata di bagian tengah tembikar. Terdapat slip yang berwarna merah pada bagian dalam gerabah dan warna hitam pada bagian luar.

Gaya (style): tidak terdapat hiasan pada pecahan mulut tembikar ini.

Teknologi: pada bagian dalam striasi yang padat, halus dan berkesinambungan yang menunjukan penggunaan roda putar cepat. Bahan yang dipakai adalah tanah liat dengan partikel halus dan tekstur rapat. Adonan yang dipakai adalah adonan halus. Bagian dalam berwana putih abu-abu merata yang menunjukan pembakaran pada tahap oksidasi dan vitrifikasi. Keramik berasal dari Eropa.

Gaya (Style): terdapat logo pabrik yang berlambang singa berkepala manusia dengan posisi duduk. Juga terdapat tulisan
"Pstrus Regouts\&Co. MAASTRICHT. MADE IN HOLLAND". Serta terdapat tulisan huruf pallawa sebanyak tiga baris. logo dan tulisan berwarna hijau-kehitaman.

Temuan keramik yang dianalisa adalah temuan lepas pada pemukiman warga.

Bentuk: pecahan yang ditemukan merupakan bagian dasar dengan diameter $5,9 \mathrm{~cm}$, tebal bagian kaki $3 \mathrm{~mm}$, tebal bagian dasar $4 \mathrm{~mm}$ keliling lingkaran 19,7 $\mathrm{cm}$. Berat temuan pecahan $110 \mathrm{gr}$. Temuan ini merupakan pecahan mangkuk.

Teknologi: pada badan bagian dalam terdapat striasi yang padat, halus dan berkesinambungan yang menunjukan penggunaan roda putar cepat. Bahan yang dipakai adalah tanah liat dengan partikel halus dan tekstur rapat. Adonan yang dipakai adalah adonan halus. Bagian dalam keramik berwarna putih abu-abu menunjukkan pembakaran pada tahap oksidasi dan vitrifikasi. Terdapat bekas tumpangan saat pembakaran pada bagian dalam (spurmark). Keramik temuan ini berasal dari dinasti Qing (1644-1911).

Gaya (style): terdapat glasir pada kedua sisi keramik dengan warna polikrom (putih-biru). Warna dasar keramik berwarna putih, sedangkan warna hiasan berwarna biru. hiasan pada pecahan mangkuk bermotif geometris.

\section{Nilai Sejarah Sejarah Desa Durian Gadis}

Lapisan tanah desa Durian Gadis menyimpan artefak budaya sebelum tahun 1960-an, dengan lapisan sejarah sebagai berikut:

Lapisan Sejarah Zaman Kerajaan Sriwjaya: Lapisan sejarah zaman kerajaan Sriwijaya diwakili dengan temuan lepas permukaan di areal pekarangan penduduk berupa pecahan bibir guci dari masa dinasti Sung (960-1279 Masehi), bahan keramik stone ware (bahan batuan) glasir tipis bening masih tersisa melapisi warna dasar bahan yaitu kuning kecoklatan. Temuan lain adalah piring dari masa yang sama dengan 
kondisi 50\% utuh. Bahan dasar stone ware dengan warna dasar putih susu dilapisi gasir bening.

Temuan survei permukaan dan survei stratigrafi kotak 1 di desa Durian Gadis menunjukkan desa ini dahulunya merupakan bagian dari kawasan perekonomian kuno di lahan basah Air Sugihan. Arsip Cina mencatat Sriwijaya mengirimkan misi dagang kenegaraan ke istana dinasti Sung mencatat 20 kali dikirim tahun antara tahun 960-1087 Masehi dan 8 kali misi dagang kenegaraan Sriwijaya dikirim ke istana dinasti Sung tahun 12001276 Masehi (Wade, 2009:227).

Pengangkutan komoditas perdagangan dari China ke Sumatera pada masa dinasti Sung tercatat 136 kali pelayaran dari tahun 947-1106 Masehi. Bahan utama yang diperdagangkan ke Selatan adalah keramik, tekstil, peralatan besi, perangkat musik, koin, dan sebagainya. Perdagangan Cina ke Sumatera tercatat telah dilakukan sejak zaman dinasti Han dan dinasti Tang. Penemuan keramik dari masa Sung di desa Durian Gadis mengindikasikan bahwa penduduk kawasan telah mengkonsumsi produk perdagangan impor dari Cina sejak abad 9-11 Masehi (Wade, 2009:226).

Produk perdagangan lokal Sumatera termasuk dari kawasan Air Sugihan yang diekspor dan diperdagangkan di kawasan Asia Tenggara dan kawasan Cina daratan antara lain: kamper, tekstil, getah pohon damar, getah gum, lak, pinang, cangkang penyu, kayu wangi, cardamom, lada, kemiri, bulu burung kingfisher, burung dan koral (Wade, 2009:244). Data temuan di desa lain yang berjarak 5 kilometer dari lokasi penelitian ditemukan struktur bangunan bata dengan panjang 18 meter dengan jumlah lapisan 5-10 bata di desa Sako kecamatan Rambutan. Temuan di Muara Sugihan Banyuasin menemukan sisa bangunan kayu pemukiman dari awal abad Masehi sampai abad ke-5 Masehi, dengan temuan lain berupa keramik, tembikar, manik-manik, arca, koin, benda logam, perhiasan serta tulang kerangka manusia.

Lapisan Sejarah Zaman Kesultanan Palembang Darussalam: Masa kesultanan Palembang Darussalam dapat dibagi menjadi masa awal kesultanan Palembang/pra-kesultanan dan masa kesultanan Palembang Darussalam. Periodesasi masa ini dimulai dari tahun \pm 1540-1823 Masehi, berakhirnya periode ini ditandai dengan kejatuhan kesultanan Palembang Darussalam ke tangan Belanda pada akhir perang Menteng.

Temuan lapisan sejarah zaman kesultanan Palembang antara lain: Penemuan makam-makam tokoh penyebar Islam yang diyakni oleh masyarakat desa Durian Gadis memiliki karomah dan sakti yang dapat memberikan pertolongan bagi warga desa yang meminta pertolongan. Nisan-nisan tersebut gaya hiasnya yang sama dengan nisan-nisan yang ada di komplek pemakaman Kesultanan Palembang Darussalam di kota Palembang. Nama-nama puyang, antara lain: (a) Puyang Canggah, (b) Puyang Kakap Panjang adalah ulama Jawa yang menyebarkan agama Islam di daerah Durian Gadis. Puyang cendikat merah (Getang). Data temuan fragmen keramik Cina dari masa dinasti Ming dan dinasti Qing. Dinasti Ming berkuasa di Cina dari abad 13-17 Masehi. Temuan keramik dari masa dinasti Ming umumnya berupa wadah: piring, mangkuk, vasu, buli-buli, cupu, ceret, patung, guci, sendok.

Berakhirnya kekuasaan dinasti Ming di Cina dilanjutnya dengan berkuasanya dinasti Qing. pada awalnya bernama "Dinasti Jin Akhir". Berdiri pada tahun 1616 hingga keruntuhannya tahun 1912. Secara resmi, Dinasti Qing menggantikan Dinasti Ming tahun 1644 ketika masa pemerintahan Kaisar Shunzhi. Ciri keramik dinasti Qing adalah penggunaan warna biru kehitaman sebagai aksesn dekoratif di atas warna dasar putih dengan glasir bening. Warna lain yang umum digunakan adalah warna 
dekoratif hijau dan kuning serta warna merah darah. Lukisan pada bidang dekoratif lebih mengarah ke aktivitas keseharian, flora dan fauna, motif geometris cerita dewa, pada bagian dasar benda biasanya tertera stempel pabrikan. Penggunaan stempel pabrikan umum digunakan pada keramikkeramik pada masa dinasti Qing. Jenis wadah yang ditemukan seperti: piring, mangkuk, vasu, buli-buli, cupu, ceret, patung, guci, sendok, vas bunga, pot bunga.

\section{Lapisan Sejarah Zaman Kolonial}

Belanda: Kejatuhan kesultanan Palembang Darussalam ke tangan penguasaan asing (Belanda), wilayah eks kesultanan Palembang dan pengaruhnya dimasukkan ke dalam wilayah administrasi baru yaitu Keresidenan Palembang, termasuk di dalamnya kepulauan Bangka Belitung, Lampung, Jambi, dan Bengkulu. Dalam laporan kolonial daerah Palembang dan pedalaman sangat dikenal dengan keunikan dan kebiasaannya. Juga dalam bidang agama masih ada perbedaan. Daerah pedalaman diperintah oleh utusan raja (jeneng). Suatu bentuk pemerintahan baru dijalankan yang dengan tetap mempertahankan unsur-unsur lama yang masih baik terutama lembaga adat dan bentuk-bentuk pemerintahan asli (pasirah, pembarap, penggawa, penghulu dan khatib) atas dasar semangat pandangan rakyat.

Tinggalan-tinggalan arkeologis dari bangsa-bangsa Eropa yang ditemukan di desa Durian Gadis berupa pecahan keramik Eropa baik yang berbentuk piring kangkung, teko dan vas bunga dengan hiasan-hiasan yang ditemukan pada keramik-keramik Eropa berupa gambaran kegiatan manusia sehari-hari, gambar hewan. Hiasan-hiasan pada keramik Eropa menggunakan teknik stiker, serta setiap hasil produk keramik Eropa biasanya disertai dengan logo atau merek pabrik.

Lapisan Sejarah Zaman Penjajahan Jepang: Tinggalan-tinggalan arkeologis dari zaman penjajahan Jepang yang ditemukan di desa Durian Gadis. Survei permukaan yang dilakukan dan pembukaan kota gali di desa durian Gadis menemukan data: 1) Temuan keramik Jepang berupa pecahan piring Imari dengan warna dasar berglasir putih dengan hiasan bermotif meander berwarna biru; 2) Mangkuk biru putih dengan teknik hiasan stiker/tempel motif bunga sakura; 3) Temuan sisa barak, dapur umum, tungku masak dan sumur, markas Jepang di tengah kebun karet milik penduduk; 4) temuan sisa jalan tanah yang dibuka pada masa penjajahan Jepang (jalan Jepang); 5) sisa lapangan terbang perintis yang dibuka oleh Jepang.

\section{SIMPULAN}

Desa Durian Gadis menyimpan data sejarah dan data budaya dari beragam lapisan sejarah dari lapisan sejarah zaman Sriwijaya; lapisan sejarah zaman kesultanan Palembang Darussalaman; lapisan sejarah zaman kolonial; lapisan sejarah zaman penjajahan Jepang.

Pemanfatan sejarah desa Durian Gadis sebagai sumber pembelajaran sejarah Sosial Ekonomi Indonesia oleh dosen akan terkendala teknis dan non teknis apabila dosen tidak mendapat bantuan teknis dalam pemanfaatan hasil penelitian.

Bentuk bantuan teknis yang diberikan pada dosen dalam upaya pemanfaatan materi hasil penelitian nilai sejarah desa Durian Gadis adalah dengan: penyusunan buku materi sejarah desa Durian Gadis; penyusunan pedoman perencanaan pemanfaatan materi; Perencanaan media pembelajaran yang tepat; Perencanaan metode pembelajaran yang tepat; Perencanaan bentuk evaluasi pembelajaran yang tepat.

\section{DAFTAR PUSTAKA}

Adelaar, K. Alexander. 2004. Where does Malay Come From? Twenty Years of Discussions About Homeland, Migrations and Classifications. 
Bijdragen tot de taal, Land en Volkenkunde. Vol.160. No.1 (2004). Pp.1-30.

Agung S.L dan Sri Wahyuni. 2013. Perencanaan Pembelajaran Sejarah. Yogyakarta: Ombak.

Andaya, Barbara Watson. 1986. The Cloth Trade in Jambi and Palembang Society during the Seventeenth and Eightteenth Centuries.

Arikunto, Suharsimi, 2002. Prosedur Penelitian Suatu Pendekatan Praktik. Jakarta: Rhineka Cipta.

Budisantosa, Tri Marhaeni S. 2012. Kepurbakalaan Dataran Tinggi Jambi dalam Pandangan Kajian Austronesia. Palembang: Jurnal Siddhayatra.

Coedes, George. 2014. Indianisasi Asia Tenggara. Depok: Komunitas Bambu.

Hanafiah, Johan. 1995. Melayu-Jawa. Citra Budaya dan Sejarah Palembang. Jakarta: PT. RajaGrafindo Persada.

Indriastuti, Kristantina. 2012. Bentuk dan Karakter Megalitik di Kecamatan Dempo Utara Kota Pagar Alam, Prov. Sumatera Selatan. Palembang: Jurnal Siddhayatra.

Milles, B. dan A. Michael Huberman. 1992. Analisis Data Kualitatif. Jakarta: UI Press.

Moeleong, Lexy J. 2000. Metodologi Penelitian Kualitatif. Bandung: PT. Remaja Rosdakarya.

Narwanti dan Somadi. 2012. Panduan Menyusun Silabus dan Rencana Pelaksanaan Pembelajaran.

Yogyakarta: Familia
Poesponegoro, Marwati Djoened, dkk. 2010. Sejarah Indonesia.1. Jakarta: P.N. Balai Pustaka

Robert, R.W. 1986. Notes on Events in Palembang 1389-1511 The Everlasting Colony. Journal of the Malaysian Branch of the Royal Asiatic Society, vol.59. No.1 (250. Pp.73-83.

Sanjaya, Wina. 2012.Perencanaan dan Desain Sistem Pembelajaran. Jakarta:Kencana.

Santun, Dedi Irwanto. 2010. Palembang, Venezia dari Timur. Yogyakarta: Ombak.

Siregar, Sondang. 2012. Pemukiman Budaya Megalitik di Situs Banding Agung Kecamatan Ogan Komering Ulu. Palembang: Jurnal Siddhayatra.

Sutopo, H.B. 2006. Metodologi Penelitian kualitatif. Surakarta: UNS. Press.

Tim Badan Pemberdayaan Masyarakat dan Pemerintahan Desa Banyuasin. 2012. Pedoman Pemberdayaan Desa. Banyuasin.

Wade, Geoff. 2009. An Early Age of Commerce In Southeast Asia, 9001300 CE. Journal of Southeast Asian Studies. Vol.40. no.2 (Jun,2009). Pp.221-265.

Yin, Robert. K. 2009. Studi Kasus Desain dan Metode. Jakarta: PT. RadjaGrafindo Persada.

Arsip:

- Jaarlijksch Verslag van de Residenche 1834-1850

- $\quad$ Bundel Palembang No.62.7

- Politick verslag van de Residentie 1856. 